\title{
The Magnitude of the Variation in Glycemia: A New Parameter for Risk Assessment in Acute Coronary Syndrome?
}

\author{
Silvia Monteiro, ${ }^{\mathrm{a}, \mathrm{b}}$ Francisco Gonçalves, ${ }^{\mathrm{a}}$ Pedro Monteiro, ${ }^{\mathrm{a}, \mathrm{b}}$ Mario Freitas, ${ }^{\mathrm{a}, \mathrm{b}}$ and Luis A. Providência ${ }^{\mathrm{a}, \mathrm{b}}$
}

${ }^{a}$ Departamento de Cardiologia, Hospital Universitario de Coimbra, Coimbra, Portugal

${ }^{\mathrm{b}}$ Facultad de Medicina de Coimbra, Coimbra, Portugal

Introduction and objectives. The aim was to evaluate the relationship between the magnitude of the variation in the level of glycemia during hospitalization and in-hospital and long-term mortality and postdischarge endpoints in 2 groups of patients with acute coronary syndrome: those with and those without a previous diagnosis of diabetes.

Methods. The study included 1210 patients admitted for acute coronary syndrome between May 2004 and July 2007. The study population was divided in 2 subgroups: patients with previous diagnosis of diabetes $(n=386)$ and nondiabetics $(n=824)$. Each subgroup was further divided into 4 smaller groups according to the quartile of glycemia variation: diabetics (Q1: $<46 \mathrm{mg} / \mathrm{dL}$; Q2: 46-88 mg/dL; Q3: 88-164 mg/dL; Q4: $\geq 164 \mathrm{mg} / \mathrm{dL}$ ) and nondiabetics (Q1: <14 mg/dL; Q2: 14-30 mg/dL; Q3: $30-$ $60 \mathrm{mg} / \mathrm{dL}$; Q4: $\geq 60 \mathrm{mg} / \mathrm{dL}$ ). Patients were followed up for an average of 18 months after the occurrence of the acute coronary syndrome.

Results. In diabetic patients, there was no relationship between the magnitude of the glycemia variation and in-hospital or postdischarge endpoints. In nondiabetics, no significant differences was observed in in-hospital mortality or morbidity; but statistically significant clinical differences were found during follow-up. Multivariate regression analysis showed that $Q 4$ versus $Q 1$, age $\geq 70$ years, and previous antiplatelet or angiotensin-converting enzyme inhibitor therapy were independent predictors of postdischarge endpoints in the nondiabetic group.

Conclusions. In nondiabetic acute coronary syndrome patients, the magnitude of the variation in glycemia observed during hospitalization was a strong independent predictor of postdischarge clinical endpoints.

Key words: Admission glycemia. Magnitude of glycemia variation. Acute coronary syndrome. Metabolic control. Prognosis.

\section{SEE EDITORIAL ON PAGES 1092-4}

Correspondence: Dra. S. Reis Monteiro. Departamento de Cardiologia. Hospital Universitario de Coimbra. P. Prof. Mota Pinto. 3000-075 Coimbra. Portugal.

E-mail: silvia.reis.monteiro@gmail.com

Received February 9, 2009

Accepted for publication April 15, 2009.

\section{Magnitud de la variación de la glucemia: ¿un nuevo instrumento para la evaluación del riesgo en el síndrome coronario agudo?}

Introducción y objetivos. Evaluar la relación entre la magnitud de la variación de la glucemia durante la hospitalización y la mortalidad hospitalaria y a largo plazo, y otras variables de valoración posteriores al alta, en 2 poblaciones con síndrome coronario agudo: pacientes con o sin diagnóstico previo de diabetes.

Métodos. Estudiamos a 1.210 pacientes ingresados por síndrome coronario agudo entre mayo de 2004 y julio de 2007. Dividimos la población en 2 subgrupos: pacientes con un diagnóstico previo de diabetes $(n=386)$ y pacientes no diabéticos $(n=824)$. Cada una de estas subpoblaciones se dividió en 4 grupos, según los cuartiles de variación de la glucemia: diabéticos (Q1 < 46, Q2 46-88, Q3 88-164, Q4 $\geq 164 \mathrm{mg} / \mathrm{dl}$ ) y no diabéticos (Q1 $<14$, Q2 14-30, Q3 30-60, Q4 $\geq 60$ mg/dl). Se efectuó un seguimiento durante una media de 18 meses tras el síndrome coronario agudo.

Resultados. En los pacientes diabéticos no hubo relación alguna entre la magnitud de variación de la glucemia y las variables de valoración intrahospitalarias y posteriores al alta. En los no diabéticos, no se observaron diferencias significativas en cuanto a la morbimortalidad hospitalaria, pero sí hubo diferencias estadísticamente significativas en el seguimiento clínico. Tras un análisis de regresión múltiple, el cuartil Q4 frente al Q1, la edad $\geq 70$ años y los antecedentes previos de tratamiento con antiagregantes plaquetarios o con inhibidores de la enzima de conversión de angiotensina fueron factores predictivos independientes para las variables de valoración posteriores al alta en el grupo no diabético.

Conclusiones. En los pacientes con síndrome coronario agudo no diabéticos, la magnitud de variación de la glucemia durante la hospitalización es un factor predictivo independiente y potente de las variables de valoración posteriores al alta.

Palabras clave: Glucemia al ingreso. Magnitud de variación de la glucemia. Síndrome coronario agudo. Control metabólico. Pronóstico. 


\section{ABBREVIATIONS \\ ACS: acute coronary syndrome \\ AMI: acute myocardial infarction \\ NSTEMI: non-ST elevation myocardial infarction \\ STEMI: ST elevation myocardial infarction}

\section{INTRODUCTION}

Stress hyperglycemia is a common finding in patients with acute myocardial infarction (AMI), which has been recognized as an acute metabolic stress. Several studies have shown that hyperglycemia on admission in acute coronary syndrome (ACS) patients is common, being associated with an increased risk of death and inhospital morbidity. ${ }^{1-11}$

Although most studies have focused their attention on the prognostic value of blood glucose at admission, the assessment of blood glucose levels during hospitalization is gaining a growing importance. However, little is known about the prognostic value of the magnitude of glycemia variation during an ACS.

The aim of this study was to evaluate the impact of magnitude of glycemia variation during hospitalization on short and long-term prognosis, in 2 ACS populations - patients with and without previous diagnosis of diabetes-, and to identify independent predictors of post-discharge endpoints in these populations.

\section{METHODS}

We performed a retrospective analysis of a database including 1210 consecutive patients admitted to a single coronary care unit for ACS, between May 2004 and July 2007.

ACS were defined according to current guidelines as unstable angina, non-ST elevation (NSTEMI), and ST elevation myocardial infarction (STEMI). ${ }^{12,13}$

Casual (non-fasting) plasma glucose was measured at hospital admission and magnitude of glycemia variation was defined as the difference between admission glycemia and the lowest fasting glycemia during hospitalization.

Our population was divided in 2 subpopulations: patients with previous diagnosis of diabetes $(n=386)$ and nondiabetics $(n=824)$. Each of these subpopulations was divided in 4 groups, according to the quartiles of glycemia variation: diabetics $(\mathrm{Q} 1$ : $<46 \mathrm{mg} / \mathrm{dL}$; Q2: 46-88 mg/dL; Q3: 88-164 mg/dL; Q4: $\geq 164 \mathrm{mg} / \mathrm{dL}$ ) and nondiabetics (Q1: $<14 \mathrm{mg} / \mathrm{dL}$; Q2: 14-30 mg/dL; Q3: 30-60 mg/dL; Q4: $\geq 60 \mathrm{mg} / \mathrm{dL}$ ).

Patients were classified as having previous diabetes if they had been given that diagnosis in the past, if their medical records contained documentation of a previous history of diabetes or if the patient was treated with an oral antidiabetic agent or insulin at the time of hospital admission.

Demographic data, cardiovascular risk factors, comorbidities, drug treatment before and during hospital stay, as well as at discharge, were collected. Furthermore, laboratorial parameters, including first blood glucose upon admission, fasting glycemia, glycated haemoglobin $\left(\mathrm{HbA}_{1 \mathrm{c}}\right)$, myocardium necrosis, inflammatory and renal function markers, haemoglobin, lipid profile, ECG data, and left ventricular ejection fraction evaluated by echocardiography were also determined.

The use and mode of reperfusion (thrombolysis, percutaneous coronary intervention, and/ or coronary artery bypass grafting) was also documented. Moreover, in-hospital morbidity, including ventricular fibrillation, cardiogenic shock, cardiac arrest, recurrent myocardial infarction, and pulmonary edema were recorded and globally assessed.

Patients were followed during an average of 18 months after ACS, by both revision of medical records and telephonic interview. Thirty-three patients $(2.7 \%$ of total population) were lost to follow-up. Readmission for ACS or worsening heart failure, non-programmed revascularization, and death were considered as post-discharge endpoints.

Analysis of group differences was performed using the Kruskall-Wallis test (median $\left[\mathrm{P}_{25}-\mathrm{P}_{75}\right]$ ) for continuous variables and $\chi^{2}$ test for trend for categorical variables. A $P$ value less than .05 was considered statistically significant. Multivariate logistic regression analysis was then performed to determine independent predictors of post-discharge endpoints. In the multivariate logistic regression analysis model, clinically relevant variables were tested: age, smoking habits, previous treatment with anti platelet agents and angiotensin-converting enzyme inhibitor (ACE inhibitors), Killip class, systolic and diastolic blood pressure at admission, heart rate at admission, left ventricular ejection fraction, creatinine clearance, C-reactive protein, and magnitude of glycemia variation.

Kaplan-Meier analysis was used to illustrate follow-up mortality and post-discharge endpoints in non-diabetic population. 
TABLE 1. Baseline Characteristics of the Nondiabetic Population

\begin{tabular}{|c|c|c|c|c|c|c|}
\hline & Total & Q1 & Q2 & Q3 & Q4 & $P$ \\
\hline Glycemia variation, $\mathrm{mg} / \mathrm{dL}$ & & $<14$ & $14-30$ & $30-60$ & $\geq 60$ & \\
\hline Patients, $n$ & 824 & 203 & 207 & 207 & 207 & \\
\hline \multicolumn{7}{|l|}{ Demographics } \\
\hline Male, $\%$ & 70.5 & 69.5 & 67.1 & 77.8 & 67.6 & .72 \\
\hline Mean age, y & 65.9 & 64.1 & 65.0 & 65.3 & 69.1 & $<.001$ \\
\hline \multicolumn{7}{|l|}{ Medical history } \\
\hline Hypertension, \% & 67.9 & 71.5 & 59.5 & 67.0 & 73.8 & .31 \\
\hline Dyslipidaemia, $\%$ & 64.2 & 62.0 & 62.3 & 63.4 & 69.6 & .19 \\
\hline Obesity, \% & 45.3 & 44.8 & 45.6 & 44.6 & 46.3 & .83 \\
\hline Smoking habits, $\%$ & 20.4 & 17.7 & 20.8 & 23.2 & 19.8 & .50 \\
\hline $\mathrm{Ml}, \%$ & 21 & 21.2 & 16.8 & 20.5 & 25.7 & .20 \\
\hline CAD, $\%$ & 58.2 & 59.7 & 61.8 & 51.7 & 59.7 & .52 \\
\hline $\mathrm{PCl}, \%$ & 13.4 & 17.2 & 11.9 & 11.3 & 13.1 & .23 \\
\hline CABG, $\%$ & 5.4 & 8 & 3.9 & 4.4 & 5.4 & .31 \\
\hline \multicolumn{7}{|l|}{ Prior medical therapy } \\
\hline Aspirin, \% & 45.9 & 51.6 & 35.8 & 46.7 & 48.9 & .88 \\
\hline Beta-blockers, \% & 31.1 & 37.9 & 34.2 & 32 & 21.5 & .004 \\
\hline ACE inhibitors, $\%$ & 44.1 & 41.9 & 41.7 & 45.9 & 46.7 & .35 \\
\hline Statins, \% & 38.1 & 45.2 & 36.7 & 32.8 & 37.8 & .19 \\
\hline Nitrates, \% & 18.2 & 24.2 & 21.7 & 14.8 & 12.6 & .006 \\
\hline Diuretics, $\%$ & 20.4 & 14.5 & 17.5 & 20.5 & 28.1 & .005 \\
\hline
\end{tabular}

ACE indicates angiotensin-converting enzyme; CABG, coronary artery bypass graft; CAD, coronary artery disease; MI, myocardial infarction; PCl, percutaneous coronary intervention.

\section{RESULTS}

In our population, $20.5 \%$ of non-diabetic patients were admitted by unstable angina, $45.5 \%$ by NSTEMI, and $34.0 \%$ by STEMI, whereas $19.5 \%$ of diabetics were admitted by unstable angina, $52.1 \%$ by NSTEMI, and $28.4 \%$ by STEMI.

Nondiabetic patients with higher magnitude of glycemia variation were older, but there were no significant differences regarding demographics in the diabetic group (Tables 1 and 2).

Risk profile was similar between quartiles. Furthermore, nondiabetic patients in higher quartiles were more often previously treated with diuretics and received less beta-blockers and nitrates, while higher quartiles of diabetics were more treated with insulin. There were no differences on other previous medications (Tables 1 and 2).

Patients in lower quartiles of glycemia variation in both the nondiabetic $(92.5 \%, 93.2 \%, 86.9 \%$, $77.8 \% ; P<.001)$ and diabetic group $(81.9 \%, 83.3 \%$, $71.9 \%, 64.6 \% ; P<.001)$ had more frequent Killip class I on admission.

Regarding admission ECG, patients in higher glycemia variation groups had more frequent ST elevation $(17.3 \%, 20.6 \%, 32.2 \%, 34.0 \% ; P<.001)$ and atrial fibrillation $(2.6 \%, 4.4 \%, 6.3 \%, 13.1 \% ; P<.001)$ in nondiabetics, while there were no differences in occurrence of ST elevation $(11.0 \%, 26.5 \%, 26.3 \%$, $21.5 \% ; P=.11)$ and atrial fibrillation $(11.0 \%, 6.1 \%$, $12.6 \%, 12.9 \% ; P=.38)$ in diabetic groups.

Mean glycemia level at admission was 131.6 (48.3) $\mathrm{mg} / \mathrm{dL}$ and 201 (81.6) $\mathrm{mg} / \mathrm{dL}$ and fasting glycemia $120(38.7) \mathrm{mg} / \mathrm{dL}$ and 177.6 (72) $\mathrm{mg} / \mathrm{dL}$, respectively in nondiabetics and diabetics. Magnitude of glycemia variation was correlated with higher levels of glycemia at admission and fasting glycemia (Tables 3 and 4).

Higher magnitude of glycemia variation was strongly correlated with higher necrosis and inflammation biomarkers in both groups, but was only associated with lower creatinine clearance in non-diabetics (Tables 3 and 4).

Regarding in-hospital drug therapy, nondiabetics in Q4 received more glycoprotein IIb/ IIIa inhibitors, diuretics and catecholamines and less beta-blockers, while diabetics received more diuretics and less ACE inhibitors and beta-blockers (Tables 5 and 6). There were no significant differences regarding other pharmacological therapies, reperfusion strategies and coronary anatomy (except less normal coronaries in higher quartiles of nondiabetics) (Tables 5 and 6). 
TABLE 2. Baseline Characteristics of the Diabetic Population

\begin{tabular}{|c|c|c|c|c|c|c|}
\hline & Total & Q1 & Q2 & $\mathbf{Q 3}$ & Q4 & $P$ \\
\hline Glycemia variation, mg/dL & & $<46$ & $46-88$ & 88-164 & $\geq 164$ & \\
\hline Patients, $\mathrm{n}$ & 386 & 94 & 98 & 97 & 97 & \\
\hline \multicolumn{7}{|l|}{ Demographics } \\
\hline Male, \% & 66.8 & 70.2 & 69.4 & 62.9 & 64.9 & .30 \\
\hline Mean age, y & 69.3 & 69.5 & 69.4 & 69.9 & 68.2 & .64 \\
\hline \multicolumn{7}{|l|}{ Medical history } \\
\hline Hypertension, \% & 82 & 84.6 & 83.2 & 78.7 & 81.5 & .44 \\
\hline Dyslipidaemia, \% & 79.7 & 77.3 & 83.6 & 82.9 & 74.6 & .71 \\
\hline Obesity, $\%$ & 62.4 & 63.3 & 65.6 & 62.4 & 58.1 & .39 \\
\hline Smoking habits, $\%$ & 9.1 & 9.6 & 11.2 & 8.2 & 7.2 & .44 \\
\hline $\mathrm{Ml}, \%$ & 30.5 & 27.5 & 31.8 & 30.8 & 31.8 & .61 \\
\hline CAD, $\%$ & 70 & 70.3 & 70.4 & 66.3 & 73.1 & .84 \\
\hline $\mathrm{PCl}, \%$ & 14.5 & 17.8 & 10.5 & 16.8 & 13 & .65 \\
\hline CABG, $\%$ & 9.3 & 8.7 & 11.3 & 4.3 & 12.6 & .72 \\
\hline \multicolumn{7}{|l|}{ Prior medical therapy } \\
\hline Aspirin, $\%$ & 47.6 & 47.1 & 50 & 47.8 & 59.4 & .55 \\
\hline Beta-blockers, \% & 29.9 & 32.9 & 29.4 & 26.1 & 31.3 & .73 \\
\hline ACE inhibitors, $\%$ & 51.7 & 47.1 & 36.8 & 40.6 & 45.3 & .79 \\
\hline Statins, $\%$ & 42.4 & 45.2 & 36.7 & 32.8 & 37.8 & .92 \\
\hline Nitrates, \% & 21 & 24.3 & 20.6 & 14.5 & 25 & .82 \\
\hline Diuretics, $\%$ & 28.8 & 30 & 26.5 & 33.3 & 25 & .76 \\
\hline Oral antidiabetics, \% & 45.4 & 57.1 & 47.1 & 42 & 34.3 & .007 \\
\hline Insulin, \% & 31.4 & 11.4 & 30.9 & 34.8 & 50 & $<.001$ \\
\hline
\end{tabular}

ACE indicates angiotensin-converting enzyme; $\mathrm{CABG}$, coronary artery bypass graft; $\mathrm{CAD}$, coronary artery disease; $\mathrm{Ml}$, myocardial infarction; $\mathrm{PCl}$, percutaneous coronary intervention.

TABLE 3. Main Laboratory Parameters of the Non-Diabetic Population

\begin{tabular}{|c|c|c|c|c|c|c|}
\hline & Total & Q1 & Q2 & Q3 & Q4 & $P$ \\
\hline Glycemia variation, $\mathrm{mg} / \mathrm{dL}$ & & $<14$ & $14-30$ & $30-60$ & $\geq 60$ & \\
\hline Patinets, $\mathrm{n}$ & 824 & 203 & 207 & 207 & 207 & \\
\hline Admission glycemia, mg/dL & $116(101.3-143.8)$ & $100(94-107)$ & $110(102-119)$ & $126.5(111-140)$ & $164(122-202)$ & $<.001$ \\
\hline Fasting glycemia, mg/dL & $110(97-130)$ & $97(90.5-102.5)$ & $105(97-115.3)$ & $115.5(102-134.3)$ & $136(111-178)$ & $<.001$ \\
\hline Peak troponin I, $\mu \mathrm{g} / \mathrm{L}$ & $11(2-36)$ & $2(0-12)$ & $8(2-25)$ & $18(4-57)$ & $20(7-57)$ & $<.001$ \\
\hline C-Reactive protein, $\mathrm{mg} / \mathrm{dL}$ & $3(1-9)$ & $1(0-4)$ & $3(1-6)$ & $5(2-11)$ & $6(2-13)$ & $<.001$ \\
\hline Creatinine clearance, $\mathrm{mL} / \mathrm{min}$ & $67(47-89)$ & $70(49-88)$ & $72(51.8-95)$ & $67(45.8-90.3)$ & $59(42-81)$ & .008 \\
\hline
\end{tabular}

TABLE 4. Main Laboratory Parameters of Diabetic Population

\begin{tabular}{|c|c|c|c|c|c|c|}
\hline & Total & Q1 & Q2 & Q3 & Q4 & $P$ \\
\hline Glycemia variation, $\mathrm{mg} / \mathrm{dL}$ & & $<46$ & $46-88$ & $88-164$ & $\geq 164$ & \\
\hline Patients, $\mathrm{n}$ & 386 & 94 & 98 & 97 & 97 & \\
\hline Admission glycemia, $\mathrm{mg} / \mathrm{dL}$ & $180(140-239.5)$ & $134.5(113.8-167.3)$ & $167(138.8-201.3)$ & $194.5(156-237.8)$ & $277(209.5-332)$ & $<.001$ \\
\hline Fasting glycemia, mg/dL & $161(126-219.5)$ & $128(106.8-163.5)$ & $145(124-187.3)$ & $178.5(133.3-232)$ & $226(157-279.5)$ & $<.001$ \\
\hline Peak troponin I, $\mu \mathrm{g} / \mathrm{L}$ & $8(1-26)$ & $3(0-15)$ & $8(3-31)$ & $10(2-26)$ & $11(2-55)$ & $<.001$ \\
\hline C-Reactive protein, $\mathrm{mg} / \mathrm{dL}$ & $4(1-10)$ & $2(1-7)$ & $4(1-11)$ & $5(2-13)$ & $5(2-15)$ & $<.001$ \\
\hline Creatinine clearance, $\mathrm{mL} / \mathrm{min}$ & $58(40-81)$ & $64(43-93.5)$ & $62.5(42.8-81)$ & $56.5(37.5-78.8)$ & $54(39-78)$ & .26 \\
\hline
\end{tabular}


TABLE 5. In-Hospital Medical Treatment and Coronary Revascularization of Nondiabetics

\begin{tabular}{|c|c|c|c|c|c|c|}
\hline & Total & Q1 & Q2 & Q3 & Q4 & $P$ \\
\hline Glycemia variation, $\mathrm{mg} / \mathrm{dL}$ & & $<14$ & $4-30$ & $30-60$ & $\geq 60$ & \\
\hline Patients, $\mathrm{n}$ & 824 & 203 & 207 & 207 & 207 & \\
\hline Aspirin, \% & 95.9 & 96.1 & 96.1 & 95.7 & 95.7 & .78 \\
\hline Clopidogrel, \% & 71.7 & 73.4 & 70.5 & 72.9 & 70 & .59 \\
\hline LMWH, \% & 97.1 & 95.1 & 98.1 & 97.6 & 97.6 & .18 \\
\hline GP Ilb/llla inhib, \% & 47.7 & 36.9 & 48.3 & 50.2 & 55.1 & $<.001$ \\
\hline Nitrates, $\%$ & 37.7 & 34 & 37.2 & 36.2 & 43.5 & .07 \\
\hline Beta-blockers, \% & 83 & 87.2 & 85.5 & 84.1 & 75.4 & .002 \\
\hline ACE inhibitors, $\%$ & 90.7 & 91.1 & 90.3 & 89.4 & 91.8 & .90 \\
\hline Statins, $\%$ & 98.3 & 96.6 & 99 & 99.5 & 98.1 & .23 \\
\hline Catecholamines, $\%$ & 2.3 & 1.5 & 1 & 1.9 & 4.8 & .02 \\
\hline Diuretics, $\%$ & 24.6 & 14.3 & 20.3 & 28.5 & 35.3 & $<.001$ \\
\hline Coronary angiography, $\%$ & 62.9 & 60.6 & 64.7 & 63.8 & 62.3 & .32 \\
\hline $\mathrm{PCl}, \%^{\mathrm{a}}$ & 62.9 & 58.6 & 58.3 & 69.6 & 65.2 & .07 \\
\hline Normal coronary angiography, \% & 14.1 & 17.9 & 19.4 & 8.3 & 10.9 & .02 \\
\hline
\end{tabular}

ACE indicates angiotensin-converting enzyme; GP Ilb/llla inib, glycoprotein Ilb/llla inhibitors; LMWH, low molecular weight heparins; PCl, percutaneous coronary interventions. aln the invasive strategy population.

TABLE 6. In-Hospital Medical Treatment and Coronary Revascularization of Diabetics

\begin{tabular}{|c|c|c|c|c|c|c|}
\hline & Total & Q1 & Q2 & Q3 & Q4 & $P$ \\
\hline Glycemia variation, mg/dL & & 46 & $46-88$ & $88-164$ & $\geq 164$ & \\
\hline Patients,n & 386 & 94 & 98 & 97 & 97 & \\
\hline Aspirin, \% & 97.9 & 96.8 & 99 & 97.9 & 97.9 & .75 \\
\hline Clopidogrel, \% & 74.1 & 73.4 & 79.6 & 66 & 77.3 & .92 \\
\hline LMWH, \% & 96.9 & 98.9 & 94.9 & 99 & 94.8 & .36 \\
\hline GP Illb/lla inhib, \% & 47.7 & 36.2 & 56.1 & 46.4 & 51.5 & .12 \\
\hline Nitrates, \% & 38.9 & 40.4 & 32.7 & 41.2 & 41.2 & .61 \\
\hline Beta-blockers, \% & 81.1 & 84 & 85.7 & 80.4 & 74.2 & .05 \\
\hline ACE inhibitors, \% & 95.3 & 97.9 & 96.9 & 96.9 & 89.7 & .01 \\
\hline Statins, $\%$ & 98.4 & 98.9 & 99 & 99 & 96.9 & .36 \\
\hline Catecholamines, $\%$ & 4.1 & 2.1 & 3.1 & 4.1 & 7.2 & .08 \\
\hline Diuretics, \% & 43.3 & 38.3 & 31.6 & 49.5 & 53.6 & .005 \\
\hline Coronary angiography, $\%$ & 50 & 52.1 & 51 & 50 & 45.9 & .38 \\
\hline $\mathrm{PCl}, \%^{\mathrm{a}}$ & 63.8 & 59.3 & 64.1 & 72.2 & 60.6 & .06 \\
\hline Normal coronary angiography, \% & 12.4 & 20.4 & 8 & 10.2 & 11.1 & .22 \\
\hline
\end{tabular}

ACE, angiotensin-converting enzyme; GP IIb/llla inib, glycoprotein Ilb/llla inhibitors; LMWH, low molecular weight heparins; PCl, percutaneous coronary interventions. aln the invasive strategy population.

Left ventricular ejection fraction, evaluated by echocardiography, was worse in nondiabetics $(58 \%$ [50\%-60\%], 55\% [47.5\%-60\%], 52\% [44\%-58\%], 50\% $[40 \%-58 \%] ; P<.001)$ and diabetics $(55.5 \%[46.3 \%-$ $60 \%$ ], 50\% [43\%-59\%], 52.0\% [45\%-58\%], 49\% [38\%$56 \%] ; P=.016)$ with higher glycemia variations. These patients also had longer hospitalizations (nondiabetics, 4 [3-6], 5 [4-6], 5 [4-6], 5 [4-7] days, $[P<.001]$; and diabetics, 4 [3-5], 4 [3-6], 6 [4-7], $6[4-8]$ days, $[P<.001])$.
In diabetic patients there was no relationship between amplitude of glycemia variation and inhospital mortality $(3.3 \%, 7.3 \%, 7.5 \%, 7.5 \% ; P=.27)$ and morbidity $(5.3 \%, 7.1 \%, 6.2 \%, 8.2 \% ; P=.50)$, and post-discharge endpoints $(38 \%, 50 \%, 40.7 \%, 48.6 \%$; $P=.39)$ and mortality $(13.2 \%, 17.1 \%, 14.5 \%, 20.0 \%$; $P=.37)$. In nondiabetics, no significant differences were observed regarding in-hospital mortality $(2.6 \%, 3.4 \%, 2.9 \%, 5.9 \% ; P=.11)$ and morbidity $(3.9 \%, 3.4 \%, 2.9 \%, 2.9 \% ; P=.52)$; however, higher 


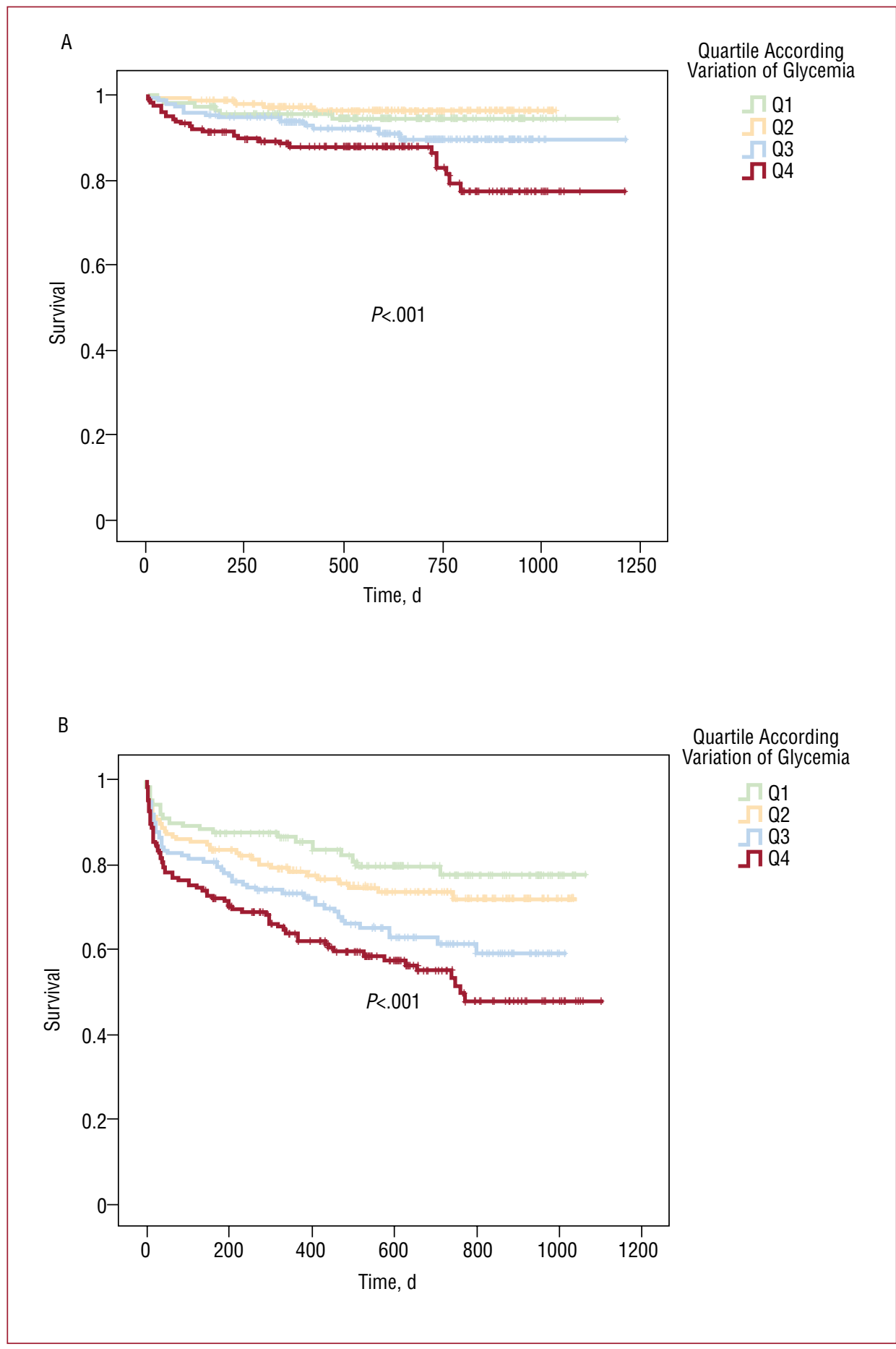

Figure. Kaplan-Meyer curves for the follow-up mortality (A) and postdischarge endpoints (B) in nondiabetic population.

amplitude of glycemia variation was associated with higher post-discharge endpoints $(22.7 \%, 26.4 \%$, $35.7 \%, 44 \% ; P<.001)$ and mortality $(4.4 \%, 4.6 \%$, $7.9 \%, 15.4 \% ; P<.001)$ during follow-up. Figure 1 shows the Kaplan-Meier curves for post-discharge endpoints and follow-up mortality in nondiabetic group.
In the overall population, total number of inhospital morbidity events was 57 , total number of in-hospital deaths was 52 and total number of postdischarged endpoints was 417 (of whom 122 were deaths).

Multivariate logistic regression analysis showed that higher magnitude of glycemia variation $(\mathrm{Q} 4$ 
TABLE 7. Independent Predictors of Post-Discharge Endpoints in Nondiabetics

\begin{tabular}{lcl}
\hline & OR $(\mathbf{9 5} \% \mathbf{~ C l})$ & $\boldsymbol{P}$ \\
\hline Q2 versus Q1 & $1.45(0.70-3.01)$ & .32 \\
Q3 versus Q1 & $1.79(0.86-3.73)$ & .12 \\
Q4 versus Q1 & $2.50(1.22-5.12)$ & .012 \\
Age $\geq 70$ years & $2.41(1.34-4.34)$ & .003 \\
Previous antiplatelet therapy & $2.02(1.25-3.25)$ & .004 \\
Previous ACE inhibitor & $1.86(1.16-2.98)$ & .01
\end{tabular}

C-statistic $=0.80$

ACE indicates angiotensin-converting enzyme; Q, quartile.

vs Q1) was an independent predictor of postdischarge endpoints in non-diabetics, as were age and previous treatment with anti-platelet agents and ACE-inhibitors (Table 7).

\section{DISCUSSION}

In this manuscript we present data on a new parameter to evaluate metabolic control in ACS patients: the magnitude of glycemia variation. Our results show that magnitude of glycemia variation was rather useful in determining post-discharge outcome, namely in the nondiabetic population, were it was an independent predictor of postdischarge endpoints in the mean 18-month followup. Logistic regression was also performed using post-ACS mortality (data not shown), but the magnitude of glycemia variation was not found to be an independent predictor.

According to the literature, hyperglycemia on hospital admission after an ACS is a common finding and should be considered an important marker of poor clinical outcome and increased mortality in patients with and without a history of diabetes. ${ }^{1-11}$

Although most studies have focused their attention on the prognostic value of blood glucose at admission, it represents only a single measurement in time and does not reflect the overall exposure to hyperglycemia during hospitalization.

There are several candidate measures to access the metabolic control in hospitalized patients. In our population, magnitude of glycemia variation during hospitalization was an independent predictor of post-discharge endpoints after ACS, in non-diabetic patients.

Suleiman et $\mathrm{al}^{14}$ showed a graded relationship between both elevated fasting glycemia and admission glycemia and 30-day mortality, in nondiabetic patients with AMI, suggesting that fasting glycemia is a more important predictor of 30-day mortality than admission glucose alone. Patients with both elevated admission glucose and elevated fasting glucose the next day had a 3-fold increase in mortality.

Similarly, failure of an elevated glucose level to normalize within $24 \mathrm{~h}$ of admission is associated with worse prognosis. ${ }^{15,16} \mathrm{~A}$ recent published study ${ }^{16}$ demonstrated that elevated admission and mean hospitalization glucose levels may be used to trigger a decision to institute intensive glucose control in hyperglycemic patients with AMI. Persistent hyperglycemia is a good discriminator of mortality, probably better than admission glucose alone in patients hospitalized with AMI..$^{14-16}$

In our non-diabetic population, we found an important association between magnitude of glycemia variation and post-discharge endpoints and mortality, unlike with in-hospital prognosis. In contrast, magnitude of glycemia variation was not related to worse prognosis in diabetic patients.

Our findings are in line with previous studies, ${ }^{2,8-10}$ which showed a different prognosis impact of stress hyperglycemia in patients without previously known diabetes and in diabetics.

There could be several explanations for this evidence. First, some patients without a history of diabetes who develop hyperglycemia in stressful situations are true diabetics or have impaired glucose tolerance. It has been reported that abnormal glucose tolerance is common among patients with AMI who have no previous diagnosis of diabetes ${ }^{17-19}$ and is a strong risk factor for future cardiovascular events. ${ }^{19}$

However, a recent study ${ }^{20}$ showed that twothirds of patients with AMI who had no previous diagnosis of diabetes had abnormal glucose tolerance by OGTT one week after AMI, regardless of admission glucose levels, and admission hyperglycemia in non-diabetics did not represent previously undiagnosed abnormal glucose tolerance.

Second, hyperglycemia in patients without diabetes is more often a marker of stress response due to more extensive myocardial damage, as a greater degree of stress is necessary to achieve the hyperglycemic state, because their metabolic control is usually normal.

Elevated glycemia after ACS in diabetic patients may be a surrogate for poor glycaemic control, associated in our study with a high short and longterm mortality, although there was not a significant relationship between quartiles of admission glycemia and higher mortality.

However, observational studies cannot distinguish whether glucose levels are merely risk markers or direct mediators of outcome following AMI. 
Current evidence suggests that hyperglycemia is a mediator of worse prognosis, directly exacerbating myocardial damage. Experimental and clinical studies have showed that hyperglycemia per se exacerbates myocardial necrosis in AMI. ${ }^{21-24}$ Higher glucose levels in AMI patients have been associated with higher free fatty acid concentrations, insulin resistance and impaired myocardial glucose use, thus increasing oxygen consumption and potentially worsening ischemia.

Acute hyperglycemia is associated with numerous adverse effects which lead to a poor outcome in ACS patients: endothelial dysfunction, platelet hyperreactivity, increased cytokine activation, increased lipolysis and free fatty acid levels, decreased glycolysis and glucose oxidation, increased oxidative stress (increased myocardial apoptosis), impaired microcirculatory function ("no-reflow" phenomenon), impaired ischemic preconditioning, impaired insulin secretion and insulin stimulated glucose uptake. ${ }^{24}$

Increased oxidative stress interferes with nitric oxide-mediated vasodilatation and reduces coronary blood flow at the microvascular level. In STEMI subjects, acute hyperglycemia is associated with decreased TIMI 3 flow before intervention, compared with euglycemia, and is the most important predictor of absence of coronary perfusion. ${ }^{25}$ It is interesting to note that in our study the performance of reperfusion therapy in STEMI patients did not independently influenced the results (data not shown).

Acute hyperglycemia is associated with impaired microcirculatory function ("no reflow" on myocardial contrast echocardiography after percutaneous coronary intervention), even in the context of angiographically successful recanalization. ${ }^{4}$ Preexisting $\mathrm{HbA}_{1 \mathrm{c}}$ levels and diabetes status do not differ between subsets with and without "no-reflow," suggesting that acute and not chronic hyperglycemia, is the dominant factor.

There is increasing evidence that tight glycemic control for patients admitted into the hospital improves clinical outcomes, especially for patients with cardiovascular disease. ${ }^{26,27}$ Recently, the DIGAMI 2 study $^{27}$ strongly supported the concept defended previously by van den Bergh, ${ }^{26}$ that a meticulous glucose control is an important goal to improve outcomes after ACS.

Compared to the other parameters of glucose metabolism control already available, namely admission glycemia and short-term glycemia normalization, the novel marker introduced in this study, magnitude of glycemia variation, has the advantage of being a more dynamic and "longitudinal" parameter, providing information about the extension of glycemia excursions during the entire ACS hospitalization, and not only a single snapshot of glucose metabolism (like admission glycemia) or a series of snapshots regarding the first $24 \mathrm{~h}$ (like the glycemia normalization). Although more complex to measure, this may be a better way of assessing metabolic stress and metabolic control during ACS, namely in non-diabetic patients. Further studies are warranted to determine if the magnitude of glycemia variation adds something to the predictive value provided by admission glycemia.

All of this data, as well as the main findings of our study, clearly stress the importance of optimum metabolic control to prevent coronary events and their frequent poor outcome, especially in high-risk populations.

\section{Study Limitations}

This study was performed based on a database of 1210 consecutive patients admitted for ACS in a single centre. However, during this time period some patients were admitted to the emergency room of our hospital with the hypothesis of an ACS and died before being admitted in the coronary care unit (mainly just before or during the attempt of primary percutaneous coronary intervention), which may have somehow influenced our results. Only 33 patients $(2.7 \%$ of the population) were lost to follow-up, a figure within expected results for a single-centre registry. The assessment of postdischarge outcomes was made by medical records revision and telephonic interview; therefore, some events may have not been adequately censored, especially if they occurred out of hospital or in other hospitals without patient referral to our centre. Causes of death were based on death certificates, if available, but in some cases the source of information was a patient's relative (therefore not always fully reliable). Although being a single-centre study, we think its results can be extrapolated for other ACS populations, because our demographic and clinical data are in line to those reported in most ACS registries published. However, large-scale clinical trials and registries are warranted to fully assess the predictive value of this and other metabolic parameters in ACS patients.

\section{CONCLUSION}

In this ACS population, magnitude of glycemia variation during hospitalization was an independent predictor of post-discharge endpoints in nondiabetic patients. This parameter, never before described, may be an important marker of metabolic control with prognostic value in these patients. This finding highlights an important potential opportunity to 
improve care and outcomes for hyperglycemic AMI patients without known diabetes.

\section{ACKNOWLEDGMENTS}

The statistical analysis was performed by Dr Adriana Belo from the National Centre for Data Collection in Cardiology, an entity of the Portuguese Society of Cardiology.

\section{REFERENCES}

1. Capes SE, Hunt D, Malmberg K, Gerstein HC. Stress hyperglycemia and increased risk of death after myocardial infarction in patients with and without diabetes: a systematic overview. Lancet. 2000;355:773-8.

2. Kosiborod M, Rathore SS, Inzucchi SE, Masoudi FA, Wang Y, Havranek EP, et al. Admission glucose and mortality in elderly patients hospitalized with acute myocardial infarction. Implications for patients with and without recognized diabetes Circulation. 2005; 111:3078-86.

3. Ishihara M, Kojima S, Sakamato T, Asada Y, Tei C, Kimura K, et al; Japanese Acute Coronary Syndrome Study Investigators. Acute hyperglycemia is associated with adverse outcome after acute myocardial infarction in the coronary intervention era. Am Heart J. 2005;150:814-20.

4. Iwakura K, Ito H, Ikushima M, Kawano S, Okamura A, Asano $\mathrm{K}$, et al. Association between hyperglycemia and the no-reflow phenomenon in patients with acute myocardial infarction. $\mathbf{J}$ Am Coll Cardiol. 2003;41:1-7.

5. Wahab NN, Cowden EA, Pearce NJ, Gardner MJ, Merry H, Cox JL. Is blood glucose an independent predictor of mortality in acute myocardial infarction in the thrombolytic era? J Am Coll Cardiol. 2002;40:1748-54.

6. Meier JJ, Deifuss S, Klamann A, Launhardt V, Schmiegel WH, Nauck MA. Plasma glucose at hospital admission and previous metabolic control determine myocardial infarct size and survival in patients with and without type 2 diabetes: the Langendreer Myocardial Infarction and Blood Glucose in Diabetic Patients Assessment (LAMBDA). Diabetes Care 2005;28:2551-3.

7. Straumann E, Kurz DJ, Muntwyler J, Stettler I, Furrer M, Naegeli B, et al. Admission glucose concentrations independently predict early and late mortality in patients with acute myocardial infarction treated by primary or rescue percutaneous coronary intervention. Am Heart J. 2005; 150:1000-6.

8. Stranders I, Diamant M, van Gelder ER, Spruijt HJ, Twisk JW, Heine RJ, et al. Admission blood glucose level as risk indicator of death after myocardial infarction in patients with and without diabetes mellitus. Arch Intern Med. 2004;164: 982-8.

9. Meisinger C, Hörmann A, Heier M, Kuch B, Löwel H Admission blood glucose and adverse outcomes in non-diabetic patients with myocardial infarction in the reperfusion era. Int $\mathbf{J}$ Cardiol. 2006;113:229-35.
10. Petursson P, Herlitz J, Caidahl K, Gudbjörnsdottir S, Karlsson $\mathrm{T}$, Perers E, et al. Admission glycemia and outcome after acute coronary syndrome. Int J Cardiol. 2007;116:315-20.

11. Monteiro S, Gonçalves F, Monteiro P, Freitas M, Providência L. Glycemia at admission: the metabolic "echocardiography" in acute coronary syndrome patients. Eur J Cardiovasc Prev Rehabil. Mar 16, 2009. [Epub ahead of print].

12. Bassand JP, Hamm CW, Ardissino D, Boersma E, Budaj A, Fernandez-Aviles F, et al. Guidelines for the Diagnosis and Treatment of Non-ST-segment Elevation Acute Coronary Syndromes. Eur Heart J. 2007;28:1598-660.

13. van de Werf F, Bax J, Betriu A, Blomstrom-Lundquist C, Crea F, Falk V, et al. Management of Acute Myocardial Infarction in patients presenting with persistent ST-segment elevation. Eur Heart J. 2008;29:2909-45.

14. Suleiman M, Hammerman H, Boulos M, Kapeliovich MR, Suleiman A, Agmon Y, et al. Fasting glucose is an important independent risk factor for 30-day mortality in patients with acute myocardial infarction: a prospective study. Circulation. $2005 ; 111: 754-60$

15. Goyal A, Mahaffey K, Garg J, Nicolau JC, Hochman JS, Weaver WD, et al. Prognostic significance of the change in glucose level in the first $24 \mathrm{~h}$ after acute myocardial infarction: results from the CARDINAL study. Eur Heart J. 2006;27: 1289-97.

16. Kosiborod M, Inzucchi S, Krumholz H, Xiao L, Jones P, Fiske $\mathrm{S}$, et al. Glucometrics in Patients Hospitalized With Acute Myocardial Infarction. Defining the Optimal Outcomes-Based Measure of Risk. Circulation. 2008;117:1018-27.

17. Bartnik M, Ryden L, Ferrari R, Malmberg K, Pyorala $\mathrm{K}$, Simoons $\mathrm{M}$, et al. The prevalence of abnormal glucose regulation in patients with coronary artery disease across Europe. The Euro Heart Survey on Diabetes and the Heart. Eur Heart J. 2004;25:1880-90.

18. Norhammar A, Tenerz A, Nilsson G, Hamsten A, Efendíc $\mathrm{S}$, Rydén L, et al. Glucose metabolism in patients with acute myocardial infarction and no previous diagnosis of diabetes mellitus: a prospective study. Lancet. 2002;359:2140-4.

19. Bartnik M, Malmberg K, Norhammar A, Tenerz A, Ohrvik J, Ryden L. Newly detected abnormal glucose tolerance: an important predictor of long-term outcome after myocardial infarction. Eur Heart J. 2005;25:1990-7.

20. Ishihara M, Inoue I, Kawagoe T, Shimatani Y, Kurisu S, Hata $\mathrm{T}$, et al. Is admission hyperglycemia in non-diabetic patients with acute myocardial infarction a surrogate for previously undiagnosed abnormal glucose tolerance? Eur Heart J. 2006; 27:2413-9.

21. Ceriello A. Acute hyperglycemia: a "new" risk factor during myocardial infarction. Eur Heart J. 2005;26:328-31.

22. Nesto R. Diabetes, Hyperglycemia, and the Cardiologist: A Call to Action for Optimizing Care. Rev Cardiovasc Med. 2006;7 Suppl 2:1-2.

23. Marfella R, Siniscalchi M, Esposito K, Sellitto A, de Fanis U, Romano C, et al. Effects of stress hyperglycemia on acute myocardial infarction: role of inflammatory immune process in functional cardiac outcome. Diabetes Care. 2003;26: 3129-35.

24. Zarich S, Nesto R. Implications and Treatment of Acute Hyperglycemia in the Setting of Acute Myocardial Infarction. Circulation. 2007;115;e436-e9.

25. Timmer J, Ottervanger J, de Boer M, Dambrink JE, Hoorntje JCA, Gosselink ATM, et al, for the Zwolle Myocardial Infarction Study Group. Hyperglycemia is an important 
predictor of impaired coronary flow before reperfusion therapy in ST-segment elevation myocardial infarction. J Am Coll Cardiol. 2005;45:999-1002.

26. van den Berghe G, Wouters PJ, Weekers F, Verwaest C, Bruyninckx F, Schetz M, et al. Intensive insulin therapy in the surgical intensive care unit. N Engl J Med. 2001;345:1359-67.
27. Malmberg KA, Rydén LE, Wedel H, Birkeland $\mathrm{K}$, Bootsma A, Dickstein K, et al; DIGAMI 2 Investigators: Intense metabolic control by means of insulin in patients with diabetes mellitus and acute myocardial infarction (DIGAMI 2): effects on mortality and morbidity. Eur Heart J. 2005;26:650-61. 